\title{
FRANCHISE AGREEMENT IN ROMANIA AS A FORM TO PROVIDE ECONOMIC EFFICIENCY OF BUSINESS ACTIVITY
}

\author{
Vitalii Vdovichen ${ }^{1}$, Oleksandr Voroniatnikov ${ }^{2}$
}

\begin{abstract}
The purpose of the article is to study the economic and legal nature of the franchise agreement in Romania. Franchising has become one of the most effective tools for economic activity and profiting in this country, and the franchising agreement is a form, in which all aspects of this activity are reflected: the rights and obligations of the parties, the price of the franchise, the duration of the franchise relations, transactions between the franchisor and the franchisee, the prohibition of competitive actions, etc. The subject of the study is the franchise agreement in Romania. Research methodology. The research is based on the use of general scientific and special-scientific methods and techniques of scientific knowledge. The dialectical method allowed us to investigate the definition of a franchise agreement in Romania and its key terms. The comparative legal method was used to compare doctrinal approaches to this issue. The statistical method was used to establish data that reflects the effectiveness of franchising activities. The method of system analysis helped to find out, in which areas of economic activity franchising is most demanded. Interpretation of the content of Romanian legal acts governing issues related to the conclusion of a franchise agreement in this country was realized with the help of the normative-dogmatic method. The system-structural method was used to study the franchise agreement in Romania as a single entity (system) with the coordinated functioning of all its elements. The methods of grouping and classifying formed the basis for separating the list of conditions, which are necessary for concluding a franchise agreement in Romania, as well as provisions that should be included in the content of this agreement. Methods of analysis and synthesis helped to study some parts of this agreement to formulate further conclusions. Practical application. The positive experience of Romania in regulating issues related to the conclusion of a franchise contract can be used for making appropriate changes to the Ukrainian legislation. Thus, in Romania, a special regulatory act (Ordinance 52/1997), which regulates the procedure for concluding this agreement, defines the rights and obligations of the parties and establishes the essential terms of the contract and the principles for its implementation, was adopted. Issues which are not regulated by the Ordinance are subject to the Civil and the Commercial Codes of the country, as well as European legislation, which sets out requirements for the prohibition of competition. Correlation/originality. This scientific work is the first research in Ukraine devoted not only to general issues of regulation of franchising activity in Europe but specifically to the franchise agreement in a separate country (in Romania) and its legal and economic peculiarities.
\end{abstract}

Key words: franchising, franchise contract, franchisor, franchisee, disclose, contract terms, anti-competitive action, resale price.

JEL Classification: K12, F55

\section{Introduction}

Franchising is an important part of the economy and the central phenomenon in entrepreneurship. In the current context, it is used as an effective tool for establishing and expanding entrepreneurial activity. In the last decade, franchising has played a key role in the development of small and medium-sized businesses; large companies use it to expand their activities, and individual entrepreneurs - to open their own business. Moreover, franchising is recommended as an active accumulation of resources for the rapid creation of large networks. In addition, it is a guarantee that entrepreneurs adhere to high standards of doing business for its successful development.

Corresponding author:

${ }^{1}$ Yuriy Fedkovych Chernivtsi National University, Ukraine.

${ }^{2}$ International Police Cooperation Department of the National Police of Ukraine, Ukraine.
Franchising is a mutually beneficial form of cooperation both for the franchisor and for the franchisee. The franchisee receives the right to sell goods or services under the trademark and using the business experience of the latter. The franchisor, in turn, receives remuneration in the form of initial and current payments.

Because of it, the economic significance of franchising attracted the attention of a wide range of researchers. In each scientific area, it received its separate definition. From the perspective of entrepreneurship, franchising is a vehicle for entering business ownership, from the perspective of marketing, franchising is an important 
distribution channel, from the perspective of economics, franchising is a leading venue for understanding the structure of contracts and from the perspective of strategic management, franchising is an important organizational form.

Franchising is a business relationship, in which the franchisor (the owner of the enterprise providing the product or service) transfers an independent person (franchisee) the right to sell and distribute franchising goods, as well as to use the business name for a fixed period of time. The International Franchise Association defines franchising as a continuing relationship in which the franchisor provides a licensed privilege to do business, plus assistance in organizing training, merchandising and management in return for consideration from the franchisee (Tripa).

The study of franchising as a type of international business was undertaken by N. V. Bezrukova, L. V. Voroniak, T. M. Hryhorenko, N. M. Hrushchynska, O. M. Kolodiziev, O. Ye. Kuzmin, A. M. Mahomedova, V. Ye. Sakharov, V. S. Tatarinov, T. M. Tsyhankova, A. V. Tsyrat, I. M. Shkola and others. However, this would be the first study in Ukraine devoted to franchising in Romania, and in particular, the economic and legal characteristics of the franchise agreement in this country.

In connection with the course of Ukraine on European integration, itis reasonable to study the positive experience of leading European countries for its further application to the legislation of our state. Therefore, the purpose of this article is to study economic and legal characteristics of the franchise agreement in Romania, which was one of the first countries in its geographic region to adopt special legislation in the field of franchising.

\section{Statement of the baseline}

Franchising is a relatively new phenomenon in the economic sphere of Romania. Until 1989, it simply did not exist in the domestic market of the country. This issue was discussed solely by the economiststheoreticians, and only in terms of commercial franchise concept and exclusively with reference to the realities of other countries.

Only with the adoption of the Law № 31/1990 on commercial companies, the development of entrepreneurship became an important component of economic restructuring. The rapid and major extension of such an economic phenomenon as franchising began in Romania. A few years later thanks to franchising, large companies of the Western world came into the country and began to set up their offices in the most varied fields of activity. The first forms of contracts, similar to the franchise agreement (distribution or affiliation), came into being after 1990. The first classical franchise company entering into Romania was McDonald's (1995) (Adriana Florina Popa, Andreea Gabriela Ponorîă).
The franchise market in Romania has undergone many changes over the last decade due to the global economic crisis that began in 2008. After 2008, there was a decrease in the number of franchises available in the market; however, since that time franchising development has generally begun. The tendency of the international franchises access to the local market continues. In 2015, the Romanian franchise market had an overall turnover of $€ 1.9$ billion ( $\$ 2.09$ billion). There are 345 active concepts, according to Inventure Franchise Consulting, 11\% more than in $2014.25 \%$ of concepts have 10 outlets or more and $50 \%$ have at least three. While the market is dominated by international franchises, future growth is expected to be fuelled primarily by domestic concepts, which currently account for one-third of the brands. Most foreign concepts originate in the United States and European countries, such as Great Britain, France, Italy, Poland, Spain, and Germany (Romania Country Commercial Guide).

Over the past ten months, the Romanian market has seen a significant increase in franchises in the retail sector (including clothing and footwear, IT and consumer electronics products) and the food and beverage sector. A report published in October 2018 by a well-known financial newspaper (Ziarul Financiar) states that that franchises, comprising over 400 business concepts, feature prominently in Romanian commerce, with cumulative revenues in of EUR 3 billion in 2017, and are experiencing a period of sustained growth.

According to the Romanian Association of Franchising in Romania, there are more than 438 franchises in various business areas. The analysis of 2633 franchise units operating in Romania determined its high popularity in such spheres as: personal services $-30.54 \%$; retail trade - 28.29\%; fast food establishments - 25.07\%; service enterprises $-6.57 \%$; interior arrangements $2.66 \%$; clothing and accessories $-2.47 \%$; food $-1.63 \%$; real estate $-1.06 \%$; construction $-0.65 \%$; restaurants and cafes $-0.65 \%$; hotels $-0.42 \%$ (Tripa).

Along with international brands, there are a number of local franchise companies acting on the Romanian market such as Jolidon, MEXTON, ID Sarrieri, Tina R, and others.

In 2006, because of the expansion of the franchise business and for the maintenance of European standards in this area, the Romanian Association of Franchising was created - a non-governmental, apolitical, non-profit organization. The goal of the organization is to identify and to solve specific franchising issues, to promote franchising as a way of doing business on the Romanian market, initiating action against illegal franchises, to combat counterfeiting and theft of know-how (Tripa).

The Romanian Association of Franchising has adopted its own Code of Ethics for Franchising in accordance with the European Code of Ethics for Franchising and the provisions of the Franchising Law. The functions of the Association include the verification of pre-contract disclose documents and franchise agreements. 
Membership in the Association is not mandatory, but it is recommended. The Association guarantees certain benefits to its members, for example, they can use the services provided by the mediation committee consisting of international experts. The latter are trying to resolve peacefully any disputes that arise between franchisors and franchisees, and they are entitled to punish them for violating the Code of Ethics for Franchising. Another advantage is providing essential information by the Association. A company that wants to become a member must pay an entrance fee, as well as annual membership fees.

Concerning the existence of legal acts regulating franchise activity and conclusion of franchise agreements, it should be noted that Romania was one of the first countries in its geographic region to adopt special legislation in the field of franchising. On August 28, 1997, the Romanian Government adopted the Ordinance 52/1997 about the legal regime applicable to franchising (Law on franchising) (Ordonanta No 52 din 28 august 1997). In accordance with this statutory act, a franchise is "a trading system based on the constant cooperation between individuals or legal entities, each of which is financially independent of the other, by which a person, called the franchisor, gives another person called the franchisee the right to work in the network or develop business, product, technology or service."

The key concept of the franchise system is the franchise network, that is, the contractual relationship established between the franchisor and one or more franchisees, which purpose is to promote technology, product or service, as well as to develop their production and distribution.

The Ordinance 52/1997 explicitly provides for the obligation of pre-contractual disclosure. According to clause 2 of the Law on franchising, at the stage of negotiations, the franchisor must provide the potential franchisee with the relevant data reflected in the so-called disclose document. The purpose of such disclosure is to enable the franchisee to evaluate probable prospects and make an appropriate decision since even if a potential franchisee has experience in the field of franchising it could be insufficient, as each franchise network has its own characteristics because it is based on the franchisor's know-how. In addition, according to Romanian law, the franchisee has no legal obligation to carry out an inspection independently before concluding a franchise agreement.

The legislator does not set any requirements for the form of the disclosure document. However, clause 2, paragraph 3 of the Ordinance 52/1997 states, which information should be included in the contents of this document: 1) the experience gained by the franchisor in the proposed business; 2) data on the financial component of the franchise agreement, such as a down payment or entry fee, periodic payments, advertising fees, tariffs for services, products, and technology, in case of stipulation on contractual obligations of their acquisition; 3) data allowing the franchisee to calculate potential profit and make a financial plan; 4) the purpose and scope of the exclusive right; 5) information on the duration, terms of renewal, settlement of disputes, and termination of the franchise agreement.

All of the above is only the minimum information that must be disclosed by the franchisor. At the request of the franchisee, the latter must provide other information, but only to the extent it is of interest to the franchisee.

Disclosure should be made in due time before the conclusion of the franchise agreement. The Ordinance 52/1997 does not directly state what the "proper term" is. As a general rule, a disclosure document must be provided before the franchisee enters into any legal obligations regarding possible cooperation.

It should be noted that there is no statutory requirement for the franchisor in Romania to disclose relevant information at the pre-contractual stage. However, in accordance with the general principle of civil law, the contracting parties must act in good faith towards each other. Thus, the franchisor's pre-contractual disclosure obligation must be interpreted both from a general contractual perspective and taking into consideration the objective and scope of the pre-contractual disclosure phase (Mihai Guia, Cosmina Raic).

It is mainly up to the franchisor to decide what amount of pre-contractual information must be provided, but the latter should always note that in case of a dispute between the parties, it will have to prove that the disclosure before the contract was sufficient enough to allow the franchisee to make a reasonable decision concerning its joining to the franchise network.

The same principle can be applied to the franchisor's obligation to provide the franchisee with technical/ commercial assistance, as well as information on any new events or facts that may significantly affect the preconditioned terms of the franchise agreement.

The law does not provide for any special sanctions in case of refusal to disclose information. However, in case of non-compliance by the franchisor with the obligation to pre-contractual disclosure information or failure to provide information about new events or facts that may significantly affect the original agreement between the parties, the franchisee has the right to file a lawsuit against the franchisor for damages caused as an effect of such non-disclosure or incomplete disclosure. The burden of proof of the existence of any damage is on the franchisee. In addition, the franchisee may require the amendment of the franchise agreement and even reduction of its financial obligations. Theoretically, criminal liability for misrepresentation is also possible (Cristina Tararache).

The franchisee, in turn, is responsible for disclosing confidential information. Clause 1184 of the Romanian Civil Code (Noul Cod Civil) stipulates that when 
confidential information is communicated by one party to another during negotiations, the other party must not disclose it or use it for themselves, whether or not they enter into a contractual relationship. Breach of this obligation causes damages, which is proportional to the damages suffered by the franchisor.

Clause 5 of the Ordinance 52/1997 provides for the points of the future agreement, which must necessarily be recorded in its content. They are: 1) the subject of the contract; 2) rights and obligations of the parties; 3) financial liabilities; 4) the term of the contract; 5) the terms for alteration, renewal, and termination of the contract.

The franchise agreement must reflect the interests of the franchise network members; protect the franchisor's rights to industrial or intellectual property by remaining general identity and reputation of the franchise network.

When concluding and executing a franchising agreement, the parties must adhere to the following principles: a) the term should be established in such a way that the franchisee could amortize the investments related to the franchise; b) the franchisor must notify the franchisee with a prior notice of his intention not to renew the contract after the expiration of its term or not to sign a new agreement; c) the circumstances, which may serve as grounds for termination of the contract without notice, should be clearly stipulated in clauses on the termination of the contract; d) the conditions under which the assignment of rights arising from the contract may be carried out should be clearly specified in the contract (in particular, the conditions for the appointment of the successor); e) preferential right should be granted if the interest in maintaining or developing a franchise network requires recognition of this right; f) non-competition clauses should be included in the contract to protect the knowhow; g) the financial obligations of the franchisee must be clearly defined and introduced in such a way as to contribute to the achievement of general aims.

With the help of the franchise agreement, the franchisor monitors compliance with all the components of the brand's image. The franchisor's trademark, a symbol of identity and reputation of the franchising network are the guarantee of the quality of the product/service/ technology provided to the consumer. This guarantee is ensured by the transfer and supervising the conformity of know-how, by providing with a homogeneous range of products and/or services and/or technologies. The franchisor guarantees that the franchisee is a financially independent person in relation to the franchisor or other persons.

Getting a set of relevant rights from the franchisor obliges the franchisee to pay fee in exchange for using the trademark of the products and/or services and/or technologies, know-how or other special knowledge associated with the franchise, as well as any other intellectual property rights or industrial property, as appropriate, the continued use of commercial and/or technical assistance provided by the franchisor during the whole term of the franchise agreement.

The Ordinance 52/1997 also specifies certain requirements for the behaviour of parties to the franchising agreement (clause 4). In particular, the franchisor must: 1) own and manage its own business for a certain period before founding a franchise network (without specifying during which period of time this activity should be carried out); 2) hold intellectual property rights or industrial design rights and transfer to the franchisee the right to exploit the trade mark, knowhow and other IPRs regarding the franchised product or service; 3 ) provide the initial training of the franchisee, as well as provide further technical and commercial support during the term of the franchise agreement; 4) advertise the franchised product or service.

In turn, the franchisee is obliged: 1) to develop the franchise network, as well as to maintain its general identity and reputation; 2) to provide the franchisor with any information meant to facilitate the analysis of the franchisee's performance and accurate financial situation; 3) not disclose to third parties the data concerning know-how both during the term of the franchise agreement and after its termination; 4) not to compete with the franchisor; 5) duly to pay the royalties and other taxes owed.

One can conclude that the requirements, which the Ordinance 52/1997 sets for the franchisor and the franchisee, aimed primarily at protecting their mutual rights and interests. Thus, the franchisor is under an obligation to prove the effectiveness of his business concept by providing data on the duration of its operation, as well as confirming the possession of intellectual property rights or industrial designs rights. In addition, it must provide initial training for the franchisee, as well as ensure its further training and technical support. In turn, the franchisee must provide the franchisor with any data necessary to improve the franchise network activity. It also has the duty not to disclose the content of know-how, which is the subject of a franchise agreement. All these measures are necessary to protect the commercial secrets of the franchisor, as well as its other intellectual property rights.

When concluding a franchise agreement in Romania, the parties, in addition to the Ordinance 52/1997, must also comply with the requirements of European legislation on anti-competitive practices (Article 101 of the Treaty on the Functioning of the European Union) and the National Competition Law № 21/2996 further amended. Franchise relations should also comply with Commission Regulation № 330/2010 on the application of Article 101 (3) of the Treaty on the Functioning of the European Union regarding the categories of vertical agreements and concerted practices, which provides the conditions under which vertical restraints are exempted from the prohibition on anti-competitive agreements. 
After concluding a franchise agreement, the franchisee usually pays an initial royalty or network entry fee. During the term of the agreement, the parties may also agree on: periodic royalties; advertising fees; exclusivity fees; other tariffs for services, products and technology that the franchisee must acquire from the franchisor under the franchising agreement.

The parties can charge interest on overdue payments either: 1) at a rate agreed by them contractually; 2 ) in the absence of an agreement, at a rate calculated by reference to the legal interest rate.

Romanian law provides that the legal interest rate for overdue payments is $8 \%$ over the interest rate of the National Bank of Romania (which is published in the Official Gazette of Romania each time it is amended). The legal interest rate is of $6 \%$ per year for contracts with a foreign/external element (for example, when the franchisor is a foreign entity) that are governed by Romanian law and for which payment was agreed to be made in foreign currency (Mihai Guia, Cosmina Raic).

The franchisor's fixing of minimum resale prices on the franchisee, whether direct or indirect, is prohibited under both European and national legislation. This is considered to be a strict restriction; in case of noncompliance, the franchisor must pay a fine of up to $10 \%$ of the registered turnover of the company until the year when it was authorized. However, maximal or nonbinding prices may be specified. There are also some exceptions to the prohibition on setting/maintaining resale prices. According to the European Block Exemption Regulation, fixing resale prices in short marketing actions shall not be subject to the restriction (Comission Regulation).

The duration of the franchise agreement in Romania is not legally determined. The parties to the agreement can define it independently and fix it in the relevant provision of the treaty. However, the minimum period of validity of the agreement, as it was stated above, must be sufficient to allow the franchisee to amortize investments related to the franchise. As a rule, a franchise agreement in Romania is concluded for a period of five to ten years.

The Ordinance 52/1997 does not contain any specific provisions on the franchisor's right to terminate the agreement before its expiration. Thus, general rules of the Romanian contract law applied, under which the contract can be terminated in the following cases: 1) for default, that is, in case of serious breach of the contract by the other party; 2) for convenience, subject to certain conditions and formalities (for example, fixedterm contracts can be terminated for convenience if the contract specifically allows it);3) by mutual agreement of the parties (Mihai Guia, Cosmina Raic).

The franchisor must inform the franchisee of any breach of the contractual obligations and give it a reasonable period to rectify this violation.

If there is no agreement on the other, the contract, as a rule, is terminated by the court. Thus, the non-defaulting party has the right to request termination before the court. The court analyses the claim and decides whether the breach was serious enough to terminate the contract or if other remedies are better suited to provide compensation to the injured party. However, the parties should stipulate the provision of the contract that provides for the possibility to terminate the agreement without applying to the court and the circumstances which may be grounds for termination of the contract.

The franchisor should not pay the compensation to the franchisee for termination of the contract, but for this, the franchisor must perform its contractual rights in good faith and within the limits of its rights. In other words, the franchisor must use its right to terminate the contract in a way that must not be deemed to be abusive by reference to normal and fair market standards (Mihai Guia, Cosmina Raic).

After termination of the agreement, post-contract relations are based on the rules of loyal competition. The franchisor can oblige ex-franchisee not to disclose information on know-how to competing franchise network, thereby securing the confidentiality of the business (clause 8 of the Ordinance 52/1997).

As we see, the provisions of the clause 8 are not obliging, that's why the franchisor must protect its rights by securing the provision on non-compete and confidentiality, preventing the transferred know-how alienation during the validity of the agreement. The Law on franchising does not provide for a period for anticompetitive actions and confidentiality, therefore, it is necessary to determine it during negotiations.

The franchise agreement can be renewed by the mutual consent of the parties; this consent must be represented in the corresponding provision of the contract. If the franchisor refuses to continue cooperation, the franchisee does not obtain the right to compensation if such a right is not stipulated in the contract itself.

\section{Conclusion}

Franchising in Romania, as in many other countries, is an effective business concept that "penetrated" to all areas of entrepreneurship, as a result of appropriate economic environment and adoption of relevant regulatory acts. Until 1989, only academic economists spoke on franchising; in practice, it did not exist in Romania because of ideological reasons. In the 1990s, fist international franchise companies arose on the territory of this country, and since the 2000s, there has been a rapid development of local franchise companies.

Legal relations between the franchisor and the franchisee are regulated by the franchise agreement, which reflects the interests of the franchise network members and protects franchisor's intellectual property rights or industrial property rights while maintaining the general identity and reputation of the franchise network. 
The issue of concluding a franchise agreement is regulated by the Ordinance № 52, which was adopted in 1997. The Civil Code and the Commercial Code of Romania will be applied where matters are not covered in the Franchise Law. The procedural aspects of entering into a franchise agreement are regulated by the Franchise
Law and the Romanian Civil Procedure Code (Nicholas Hammond, Sebastian Simon).

The parties to the agreement are free to negotiate all its provisions as long as they comply with the provisions of the Ordinance 52/1997 and the aforementioned codes.

\section{References:}

Tripa, S. Franchising as a growth strategy. Evidence from Romania. Annals of the University of Oradea fascicle of textiles, leatherwork. URL: http://textile.webhost.uoradea.ro/Annals/Vol\%20XV-no\%20II/Art.\%20nr.\%2069,\%20 pag\%20183-188.pdf

Adriana Florina Popa, Andreea Gabriela Ponorîcă. Franchising contract - a modern juridical and economic instrument for business expansion. URL: http://oaji.net/articles/2017/5275-1511862451.pdf

Romania Country Commercial Guide. Romania - Franchising. URL: https://www.export.gov/article?id= Romania-Franchising

Ziarul Financiar. Piața din România a atras aproape 400 de concepte de franciză cu afaceri cumulate de 3 mld. euro anul trecut (5 Oct. 2018). URL: https://www.zf.ro/imm/piata-din-romania-a-atras-aproape-400-de-concepte-defranciza-cu-afaceri-cumulate-de-3-mld-euro-anul-trecut-17544763

Ordonanta No 52 din 28 august 1997 privind regimul juridic al francizei: Textul actului republicat în Monitorul Oficial nr. 180/14 mai. 1998. URL: http://www.cdep.ro/pls/legis/legis_pck.htp_act_text?idt=17678

Mihai Guia, Cosmina Raic. Domestic and international franchising, master franchising, and regulation of franchise agreements in Romania: overview. Thomson Reuters. Practical Law. URL: https://uk.practicallaw.thomsonreuters.com/ 9-632-4918 bhcp $=1$ \&transitionType $=$ Default \& contextData $=($ sc. Default $) \&$ firstPage $=$ true $\&$ comp $=$ pluk

Cristina Tararache. Franchise 2019. Romania. International Comparative Legal Guides. URL: https://iclg.com/ practice-areas/franchise-laws-and-regulations/romania

Noul Cod Civil (Legea 287/2009), actualizat 2018, republicat în Monitorul Oficial nr. 505/2011, aplicabil din 1 octombrie 2011. URL: http://www.imliasi.ro/noul-cod-civil.pdf

Comission Regulation (EU) No 330/2010 of 20 April 2010 on the application of Article 101 (3) of the Treaty on the Functioning of the European Union to the vertical agreements and concerted practices categories. URL: https://eur-lex.europa.eu/legal-content/EN/ALL/?uri=CELEX\%3A32010R0330

Nicholas Hammond, Sebastian Simon. Franchising in Romania. Hammond Bogaru and Associates. Bucharest Romania. November, 2011. URL: http://www.bbnalaw.com/files/articles/Franchise_in_Romania_EN.pdf 